Section Editor Mitchell S.V. Elkind, MD, MS

Colin Quinn, MD

Chafic Karam, MD

Correspondence to Dr. Karam:

chafickaram@gmail.com

Clinical Reasoning:

\title{
A 39-year-old woman with progressive proximal weakness
}

\section{SECTION 1}

A 39-year-old woman presented with progressive weakness over the past $2 \frac{1}{2} 2$ years. She initially noticed weakness in her legs after falling while getting out of a boat. Her leg weakness slowly progressed over the next 2 years to the point where she was having great difficulty with stairs and getting up from a sitting position, particularly from low surfaces. In the 2 months prior to her initial visit, she had noticed difficulty reaching overhead. She denied any skin changes, rash, or muscle pain. She did not have any double or blurred vision, ptosis, facial weakness, dysarthria, dysphagia, shortness of breath, numbness, or tingling. Prior to the onset of her symptoms, she had no medical problems apart from asthma and was not taking any medications or supplements. A detailed family history was negative for neurologic disease. Her examination demonstrated mild weakness of the neck flexors (Medical Research Council [MRC] grade 4), and moderate, symmetric, proximal arm and leg weakness (MRC grade 3). Distal muscles were strong. Cognition, cranial nerves, muscle bulk and tone, deep tendon reflexes, sensory examination, and coordination were normal. She had a mild Trendelenburg gait. There was no myotonia or fasciculation.

\section{Questions for consideration:}

1. What is your differential to this point?

2. What testing would be helpful to narrow the differential?

\section{SECTION 2}

This patient presented with 2 years of progressive proximal weakness without sensory loss. The differential is broad and includes disorders of the muscle (both acquired and inherited), neuromuscular junction (myasthenia gravis, Lambert Eaton), motor nerves, and anterior horn cells. A CNS process affecting strength only is unlikely given the absence of pathologic reflexes, the pattern of weakness, and the absence of any cognitive, visual, and sensory findings.

Serum creatine kinase (CK) testing and an EMG were obtained by a rheumatologist she saw 2 months prior to her visit with us. Her CK was elevated up to 4,600 units/L on multiple occasions. An EMG demonstrated abnormal spontaneous activity in the form of fibrillation potentials and positive sharp waves in the proximal muscle of the arms and legs along with small-amplitude, short-duration, and complex motor unit potentials in all muscles examined. Her sensory and motor nerve conduction studies were normal.

\section{Questions for consideration:}

1. Based on these findings, what is your current differential diagnosis?

2. What testing would you perform to clarify the diagnosis?

\section{SECTION 3}

The history, neurologic examination, elevated CKs, and EMG findings point to a myopathic process. This process could be either acquired or inherited. The absence of a family history of muscle disease does not necessarily rule out a hereditary condition. And, although some inherited myopathies such as facioscapulohumeral muscular dystrophy or Miyoshi have a specific weakness pattern, differentiating limb-girdle muscular dystrophies from an acquired myopathy solely on clinical grounds

From the Department of Neurology (C.Q.), University of Massachusetts, Memorial Medical Center, Worcester; and Peripheral Neuropathy Research Laboratory (C.K.), Mayo Clinic, Rochester, MN.

Go to Neurology.org for full disclosures. Funding information and disclosures deemed relevant by the authors, if any, are provided at the end of the article. 
is difficult. Therefore a muscle biopsy is warranted for further characterization of the disease process.

When considering acquired myopathies, information regarding toxic exposures (e.g., alcohol), medications (e.g., statins, steroids, HIV medications, hydroxychloroquine, and colchicine), metabolic disturbances (e.g., hypothyroidism, adrenal insufficiency, electrolyte abnormalities), or acute illnesses (e.g., critical illness myopathy, infectious necrotizing myopathy) is critical. In the absence of any of these factors, an idiopathic inflammatory myopathy is most likely. The idiopathic inflammatory myopathies include dermatomyositis, polymyositis, immune-mediated necrotizing myopathy, and inclusion body myositis. They are detailed in the table. Defining pathologic characteristics of the inflammatory myopathy also supports the need for a muscle biopsy in this patient.

The patient underwent a muscle biopsy of the left quadriceps (figure). This demonstrated multiple necrotic muscle fibers per high-powered field. Few inflammatory cells were seen and there were no vacuoles. Immunostaining revealed no significant membrane attack complex (MAC) deposition or expression of major histocompatibility complex (MHC)-I on blood vessels or non-necrotic fibers. These findings are consistent with a necrotizing myopathy. A workup for concurrent neoplasm was performed, including a CT and PET scan of the body, and was negative. Blood count, electrolytes, thyroid-stimulating hormone, serum protein electrophoresis and immunofixation, paraneoplastic panel, cyclic citrullinated peptide, antinuclear antibodies, rheumatoid factor, Jo1 antibodies, C-reactive protein, and HIV were all normal or negative.

DISCUSSION This patient was diagnosed with immune-mediated necrotizing myopathy (IMNM). IMNMs are believed to be the product of an immune attack resulting in destruction of muscle. The muscle biopsy typically shows necrotic fibers with little inflammation. Potential triggers of this autoimmune reaction include signal recognition particle antibodies (SRP Ab) ${ }^{1,2}$ connective tissue diseases, ${ }^{3,4}$ malignancies, ${ }^{5}$ viral illness, ${ }^{6,7}$ and, most recently, statin medications. ${ }^{3,8}$ While IMNM is typically considered a rare entity, in a study of 225 muscle biopsies in patients with clinical, serologic, and electrophysiologic features of myopathy, 26 patients (10\%) were determined to have an idiopathic necrotizing myopathy. Of these 26 patients, 10 (38\%) had been exposed to statins. ${ }^{3}$

As with the other inflammatory myopathies, a subacute onset of proximal weakness appears present in most cases of IMNM. The duration of disease is somewhat unusual in the case discussed herein as most, but not all, patients present with less than 6 months of weakness. The degree of weakness in IMNM is generally thought to be greater than typical polymyositis (PM) or dermatomyositis (DM) but this is not always true and a wide breadth of clinical severity has been described. ${ }^{1,2,9}$ Myalgias may or may not be present. Dysphagia is commonly reported. ${ }^{1,2,8,9}$ Interstitial lung disease (ILD) occurs in approximately $20 \%$ of SRPpositive patients with myositis, which puts the risk of ILD at comparable levels to DM and PM. ${ }^{2}$ Given that cancer is one of the inciting factors in INMN, it stands to reason that cancer risk is increased in this population; however, this was not demonstrated in a single cross-sectional study. ${ }^{4}$

Men and women are equally at risk for IMNM after statin exposure. ${ }^{8}$ Women may more commonly develop IMNM associated with SRP Ab. ${ }^{1,2}$ The age at onset appears comparable to PM/DM.

On laboratory testing, CK levels seem to be more elevated than in other inflammatory myopathies. ${ }^{4,9}$ Needle EMG is usually consistent with an inflammatory myopathy demonstrating abnormal insertional and spontaneous activity in the form of fibrillation potentials and positive sharp waves and short-duration, low-amplitude, polyphasic motor units, which recruit early at normal frequencies. ${ }^{3,5,8}$

INMN is defined pathologically by the presence of necrotic fibers on muscle biopsy with no or minimal inflammatory infiltrate outside of areas of necrosis. The absence of inflammatory cells in non-necrotic regions is key for distinguishing IMNM from PM or inclusion body myositis (IBM). There is also no perifascicular

\begin{tabular}{|c|c|c|c|c|c|c|}
\hline Summary of idiop & c inflammato & myopa & ies $^{10}$ & & & \\
\hline Type & Age & Sex & $\begin{array}{l}\text { Predominant } \\
\text { weakness }\end{array}$ & Clinical clues & Muscle biopsy & Treatment \\
\hline Dermatomyositis & Child to adult & $\mathrm{F}>\mathrm{M}$ & Proximal & Skin rash & $\begin{array}{l}\text { Perimysial and perivascular } \\
\text { inflammation; complement } \\
\text { deposition on blood vessels }\end{array}$ & Immunomodulation \\
\hline Polymyositis & Adult & $\mathrm{F}>\mathrm{M}$ & Proximal & & Endomysial inflammation & Immunomodulation \\
\hline $\begin{array}{l}\text { Immune-mediated necrotizing } \\
\text { myopathy }\end{array}$ & Adult & $\mathrm{F}>\mathrm{M}$ & Proximal & Prior statin exposure & $\begin{array}{l}\text { Necrotic fibers with minimal } \\
\text { inflammation }\end{array}$ & $\begin{array}{l}\text { Immunomodulation } \\
\text { (typically intensive) }\end{array}$ \\
\hline Inclusion body myositis & Older adult & $M>F$ & $\begin{array}{l}\text { Quadriceps and } \\
\text { finger flexors }\end{array}$ & Dysphagia & $\begin{array}{l}\text { Endomysial inflammation with } \\
\text { rimmed vacuoles }\end{array}$ & None \\
\hline
\end{tabular}




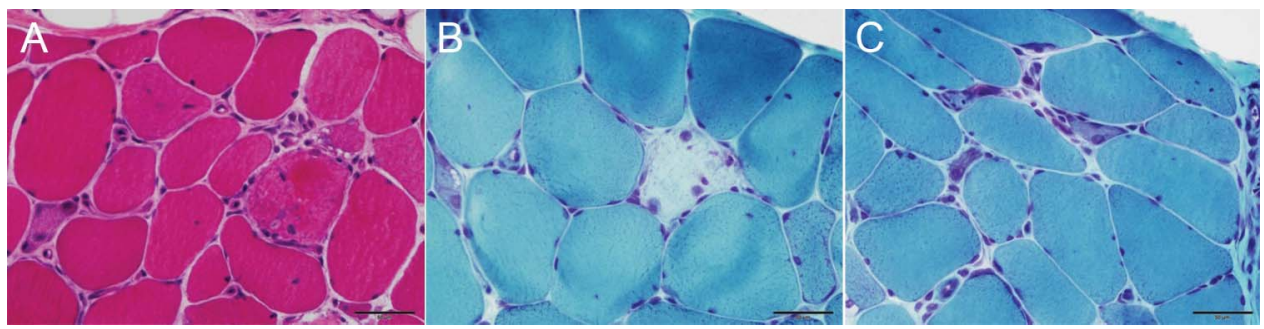

(A) Hematoxylin \& eosin stain demonstrates necrotic cells being invaded by inflammatory cells. Few inflammatory cells are seen outside these regions of necrotic fibers. (B) Gomori trichrome (GTC) stain demonstrates a degenerating fiber. (C) GTC stain demonstrates regenerating fibers.

atrophy as one would expect in DM and no rimmed vacuoles as is typically seen in IBM. Immunostaining in IMNM has revealed variable deposition of the MAC on capillaries (typically less than seen in DM) and muscle fibers ${ }^{1-4}$ as well as variable MHC-1 expression on non-necrotic fibers. ${ }^{1,3,4}$ PM and IBM are associated with diffuse MHC-I expression on muscle fibers. Despite the relative lack of inflammation, IMNM is considered to likely be autoimmune in nature due to the presence of occasional abnormalities on immunostaining, the possible association with autoantibodies and other clinical diseases associated with autoimmunity, and response to immunomodulation.

Treatment in IMNM is immunomodulatory therapy. However, IMNM is a relatively rare and newly recognized entity, and therefore specific guidelines for treatment are not well-established. IMNM can be refractory to a single agent and is inclined toward relapse $(48 \%-70 \%) .{ }^{1-3,8}$ Most authors describe using prednisone as an initial agent at a dose of 40 to $100 \mathrm{mg}$ daily. In this case, the patient had been placed on prednisone $60 \mathrm{mg}$ PO daily for 5 weeks prior to coming to our clinic with no clinical improvement. The duration of prednisone is not well-defined in the literature; however, we typically try at least 3-6 months of high-dose steroids. When the patient's strength starts to recover, we taper the prednisone very slowly and carefully. When the patient is either very weak or there is no response to high-dose prednisone and continuous decline in strength, we would add another immunomodulating agent. A secondary agent is often required, but the particular drug used varies substantially. Doses are titrated based on clinical response. We usually use methotrexate, 15 to 25 mg weekly, as a second agent, and if there is no improvement, sometimes add a course of IV immunoglobulin $2 \mathrm{~g} / \mathrm{kg}$ over 2 to 5 days for 3 months, followed by maintenance treatments every 1 to 2 months as needed. ${ }^{10}$ In paraneoplastic IMNM, removal or appropriate treatment of the inciting cancer is clearly a priority.

\section{AUTHOR CONTRIBUTIONS}

Dr. Quinn: conceptualization, design, and drafting the manuscript. Dr. Karam: conceptualization and revising the manuscript for intellectual content.

\section{ACKNOWLEDGMENT}

The authors thank Dr. Andrew Engel for providing the images in the figure.

\section{STUDY FUNDING}

No targeted funding reported.

\section{DISCLOSURE}

C. Quinn has nothing to disclose. C. Karam serves as a Deputy Editor of the Neurology ${ }^{\circledR}$ WriteClick section and served on the editorial board of the Neurology ${ }^{\circledR}$ Resident \& Fellow Section. Go to Neurology.org for full disclosures.

\section{REFERENCES}

1. Miller T, Al-Lozi MT, Lopate G, Pestronk A. Myopathy with antibodies to the signal recognition particle: clinical and pathological features. J Neurol Neurosurg Psychiatry 2002;73:420-428.

2. Hengstman GJ, ter Laak HJ, Vree Egberts WT, et al. Antisignal recognition particle autoantibodies: marker of a necrotising myopathy. Ann Rheum Dis 2006;65:1635-1638.

3. Christopher-Stine L, Casciola-Rosen LA, Hong G, Chung T, Corse AM, Mammen AL. A novel autoantibody recognizing $200-\mathrm{kd}$ and $100-\mathrm{kd}$ proteins is associated with an immunemediated necrotizing myopathy. Arthritis Rheum 2010;62: 2757-2766.

4. Ellis E, Ann Tan J, Lester S, et al. Necrotizing myopathy: clinicoserologic associations. Muscle Nerve 2012;45:189-194.

5. Levin MI, Mozaffar T, Al-Lozi MT, Pestronk A. Paraneoplastic necrotizing myopathy: clinical and pathological features. Neurology 1998;50:764-767.

6. Simpson DM, Bender AN. Human immunodeficiency virus-associated myopathy: analysis of 11 patients. Ann Neurol 1988;24:79-84.

7. Satoh J, Eguchi Y, Narukiyo T, et al. Necrotizing myopathy in a patient with chronic hepatitis $\mathrm{C}$ virus infection: a case report and a review of the literature. Intern Med 2000;39:176-181.

8. Grable-Esposito P, Katzberg HD, Greenberg SA, Srinivasan J, Katz J, Amato AA. Immune-mediated necrotizing myopathy associated with statins. Muscle Nerve 2010;41:185-190.

9. Bronner IM, Hoogendijk JE, Wintzen AR, et al. Necrotising myopathy, an unusual presentation of a steroid-responsive myopathy. J Neurol 2003;250:480-485.

10. Amato AA, Barohn RJ. Evaluation and treatment of inflammatory myopathies. J Neurol Neurosurg Psychiatry 2009; 80:1060-1068. 


\section{Neurology}

\section{Clinical Reasoning: A 39-year-old woman with progressive proximal weakness Colin Quinn and Chafic Karam Neurology 2013;81;400-402 \\ DOI 10.1212/WNL.0b013e31829c5eb0}

This information is current as of July 22, 2013

\section{Updated Information \& Services}

References

Subspecialty Collections

Permissions \& Licensing

Reprints including high resolution figures, can be found at: http://n.neurology.org/content/81/4/400.full

This article cites 10 articles, 4 of which you can access for free at: http://n.neurology.org/content/81/4/400.full\#ref-list-1

This article, along with others on similar topics, appears in the following collection(s):

Autoimmune diseases

http://n.neurology.org/cgi/collection/autoimmune_diseases Muscle disease

http://n.neurology.org/cgi/collection/muscle_disease

Information about reproducing this article in parts (figures,tables) or in its entirety can be found online at:

http://www.neurology.org/about/about_the_journal\#permissions

Information about ordering reprints can be found online:

http://n.neurology.org/subscribers/advertise

Neurology ${ }^{\circledR}$ is the official journal of the American Academy of Neurology. Published continuously since 1951, it is now a weekly with 48 issues per year. Copyright (O) 2013 American Academy of Neurology. All rights reserved. Print ISSN: 0028-3878. Online ISSN: 1526-632X.

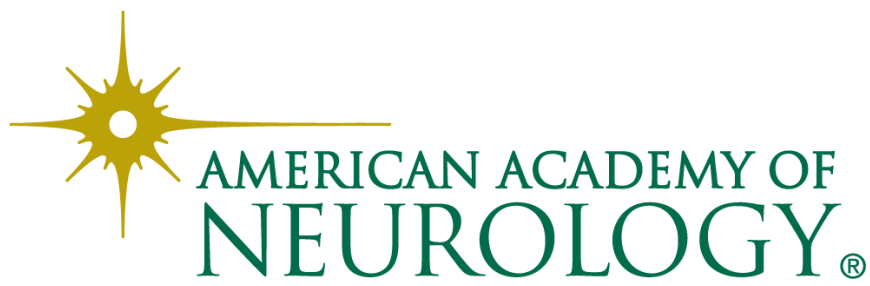

